This is the accepted version of an article published by De Gruyter in Basic Income Studies 10 (2), 193-223, final version available at: http://www.degruyter.com/abstract/j/bis.2015.10.issue-2/bis-2015-0021/bis-2015-0021.xml Accepted Version downloaded from SOAS Research Online: http://eprints.soas.ac.uk/23032/

\title{
Why Basic Income's Emancipatory Value exceeds its Monetary Value
}

\author{
Guy Standing \\ "A little more, how much it is; \\ A little less, what worlds apart." \\ - Robert Browning
}

\section{Introduction}

Between 2010 and 2013, a large-scale pilot basic income scheme was conducted in the Indian State of Madhya Pradesh. Everyone in nine villages - more than 6,000 men, women and children - received a small unconditional regular cash payment every month for 12-18 months and the impact of the basic income was evaluated by comparing outcomes with what happened in similar villages where no basic income was paid.

The evaluations showed a significant positive impact of the basic income on living conditions, health and nutrition (especially of girls), education (including girls), productive activity, women's empowerment, and the wellbeing of the elderly and disabled (SEWA Bharat, 2014; Davala et al., 2015). This article explores one set of issues arising from a striking feature of the survey results - the stronger than anticipated effects of what was a modest or "partial" basic income of about a third of subsistence.

Using these evaluation data, it is argued here that the "emancipatory" value of a basic income is greater than its "monetary" value, the main reason being that money itself is a scarce commodity for the vast majority of villagers. By contrast with the provision of subsidised goods (the most widespread form of official help for the poor in India), the emancipatory value of a basic income arises not only because recipients have more freedom to spend how, when and where they choose, but also because the basic income reduces the scarcity of the commodity of money, and thus lowers the "price" of monetary transactions.

After briefly sketching the methodology of the basic income pilot, this article discusses the notion of scarcity and its effects in relation to money, and goes on to look at the role of money in the context of Indian villages and the debt mechanisms that operate in those villages. We then consider how the impact of the basic income on debt, saving, and the response to shocks, hazards and uncertainty supports the emancipatory value claim. In concluding remarks, it is argued that the emancipatory value of a basic income will also exceed the monetary value in other contexts, including as it applies to the growing precariat around the world (Standing, 2014).

\section{The basic income pilot in Madhya Pradesh}

The basic income pilot in Madhya Pradesh consisted of a "general village" pilot and a small tribal village pilot. In the general village pilot, every man, woman and child in eight villages received a modest basic income each month for 18 months, covering about 5,500 individuals 
This is the accepted version of an article published by De Gruyter in Basic Income Studies 10 (2), 193-223, final version available at: http://www.degruyter.com/abstract/j/bis.2015.10.issue-2/bis-2015-0021/bis-2015-0021.xml Accepted Version downloaded from SOAS Research Online: http://eprints.soas.ac.uk/23032/

in 938 households. The effects were evaluated by a series of surveys that compared what happened to them with what happened to people living in twelve similar villages who did not receive a basic income. A small complementary pilot was launched later, in which all 756 residents in a tribal village were provided with a basic income for 12 months, and their experience and behaviour were evaluated by comparison with all those living in another tribal village.

The basic income was paid in addition to any other sources of state help villagers might be receiving, notably in state-subsidised rations of basic commodities through the Public Distribution System (PDS). The PDS is supposed to provide different amounts of subsidised rice, wheat, sugar and kerosene, sold in ration shops, to those possessing Antyodaya (AYY) cards (for the poorest), Below-Poverty Level (BPL) cards or Above-Poverty Level (APL) cards. However, for various reasons, most subsidised goods - as much as 75 per cent, on official estimates -- do not reach the intended beneficiaries (for an analysis, see Jhabvala and Standing, 2010). ${ }^{1}$

A unique feature of the larger general village pilot was its design to test for the independent effect of Voice, that is, the presence of a collective body that could represent the interests of vulnerable members of the community. The hypothesis was that such a body would reduce the vulnerability of recipients of a basic income and thus make the effects more positive, or stronger (this is argued in, for example, Standing, 2005; Standing, 2014).

Accordingly, in four of the villages in which everybody received the basic income, the women's organisation SEWA (Self-Employed Women's Association of India) had been active for five or more years, while in the other four SEWA was not operating. And, correspondingly, in six of the twelve control villages SEWA was operative, not in the others.

The impact of the basic income was evaluated by four detailed surveys - a baseline survey conducted just before the launch of the pilots, an interim evaluation survey (henceforth, IES) conducted about mid-way through them, a final evaluation survey (FES) conducted after 12 months from the start, and a post-final evaluation survey (PFES) in two basic income villages to collect impressions after the 18 months covered by the pilot had been completed. The baseline survey and the FES were censuses, covering all households; the IES was a 50 per cent random sample of households. ${ }^{2}$

Alongside the evaluation surveys, one hundred structured interviews were conducted, with several visits to each of the selected households. For these case studies, questions were specified in advance and, as with the evaluation surveys, the fieldwork was conducted by

\footnotetext{
${ }^{1}$ In 2013, the PDS was extended by the Food Security Act, rushed through by the Congress-led government in a vain attempt to forestall defeat in the general election of 2014.

${ }^{2}$ In the IES and FES, 50 per cent of respondents were women. Errors by the institute commissioned to conduct the baseline survey made it necessary to rely on retrospective data in the IES and FES to a greater extent than planned. And the IES was postponed slightly due to adverse weather and an outbreak of typhoid in the region. The FES was actually conducted before the end of the pilot, as additional money became available that enabled the pilot to be extended from the original 12 to 18 months.
} 
This is the accepted version of an article published by De Gruyter in Basic Income Studies 10 (2), 193-223, final version available at: http://www.degruyter.com/abstract/j/bis.2015.10.issue-2/bis-2015-0021/bis-2015-0021.xml

Accepted Version downloaded from SOAS Research Online: http://eprints.soas.ac.uk/23032/

independent enumerators who were not members of the research team and who were instructed to give no guidance to recipients on how to spend the money.

Before the pilots began, an Awareness Day was held in each village selected for the basic income, in which it was announced that everybody was free to spend the money as they wished and would not be guided or criticised in any way. In the larger pilot, the basic income was initially paid in cash and then into individual bank accounts, which villagers without existing accounts were helped to open. In the tribal village, there was no requirement to open a bank account. In both pilots, mothers received the money for children.

The basic income in the general village pilot was 200 Rupees for each adult per month and 100 Rupees for each child under the age of 14, which was raised to 300 Rupees and 150 Rupees respectively for the final six months. ${ }^{3}$ In the year covered by the tribal village pilot, each adult received 300 Rupees per month and each child received 150 Rupees.

\section{The Lauderdale Paradox}

The Lauderdale Paradox, first formulated by the eighth Earl of Lauderdale in 1804, states that as private wealth accumulates public wealth declines, because the private acquisition of assets makes them scarcer and so raises their price. Scarcity is a prerequisite for something to have exchange value, that is, to become a commodity. We may say that a good or service is a contrived scarce commodity if, in addition to having exchange value, the amount available is limited by a minority's control of it.

In Indian villages, money itself is a scarce commodity. This arises partly because people are income poor and because the amount of cash in circulation is limited by the traditional tendency to 'keep money under the bed'. But its scarcity is also contrived, in that landlords in alliance with moneylenders, a tiny minority, monopolise and restrict its supply. As we shall see, they restrict the flow of money to those who perform labour, for example, through demanding labour in payment of debt, while the shortage of cash is strengthened by a traditional practice among those supplying goods and services to receive payment in nonmoney form. As a consequence, most people are permanently in debt or in need of cash without easy means of obtaining it.

Maintaining scarcity of a commodity that is price-inelastic - because everybody needs money when money is the primary unit of exchange - has driven up the cost of loans, debt, and the prospective costs of shocks and hazards, thereby limiting, or blocking, potential economic growth of the village economy. Given the growing reliance on money in the Indian economy, its scarcity value must rise. Having money per se has become more important.

We can thus hypothesise that a basic income, by providing a cash income stream over time, will increase the supply of money, reduce its price, and thereby reduce the power of the moneylenders and landlords to contrive its scarcity, with implications for embedded power relationships in the villages.

\footnotetext{
${ }^{3}$ At the time of the pilot, one US dollar was worth just over 50 Rupees.
} 
This is the accepted version of an article published by De Gruyter in Basic Income Studies 10 (2), 193-223, final version available at: http://www.degruyter.com/abstract/j/bis.2015.10.issue-2/bis-2015-0021/bis-2015-0021.xml Accepted Version downloaded from SOAS Research Online: http://eprints.soas.ac.uk/23032/

\section{Scarce commodity, "scarcity mind-set"}

In addition, the scarcity of key commodities induces individual and community psychological effects. Research suggests that people who sense a scarcity of money - or scarcity of time or food - are prone to suffer from a "scarcity mind-set" (Mullainathan and Shafir, 2013; Mani et al., 2013). This shapes behaviour and attitudes in debilitating or welfare-reducing ways. It shortens people's planning horizons and narrows perspectives, blocking out consideration of some options, and produces chronic anxiety.

Economic insecurity impedes cognitive capacity by taking up too much "mental bandwidth" (Mani et al., 2013). ${ }^{4}$ Thus, for example, it has been found that Indian farmers score worse on standard intelligence tests before a harvest when money is scarce, and that feeling poor in terms of access to money lowers a person's IQ by as much as a night without sleep (Mullainathan and Shafir, 2013).

Scarcity also colonises the mind. It weakens the will, which helps perpetuate the scarcity, because people cannot psychologically prepare to take initiatives or entrepreneurial risks. This helps to explain the failure of many well-intentioned schemes to assist the income poor; the intended recipients cannot sustain the effort or will-power to take advantage of them.

Conversely, if insecurity and the scarcity of a key commodity make people less intelligent (in the short-term sense), or experience a shortfall of cognitive resources, then having income security and monetary liquidity should have the opposite effect. This has profound implications, for mental capacity and for behaviour. Put bluntly, if money is a vital scarce commodity, its absence will induce those without it to make risk-averse choices, to satisfice rather than to try to maximise. ${ }^{5}$ If it becomes less scarce, that should induce more rational, entrepreneurial or longer-term decision making.

\section{Conceptualising Insecurity}

\section{"Insecurity is worse than poverty."}

\section{- Confucius.}

To appreciate fully the emancipatory value of a basic income, the concept of economic security needs to be unbundled. Its inverse, insecurity, arises from the combination of risk, hazards, shocks and uncertainty.

Any action involves risk. Twentieth-century welfare states were based on what have been called contingency, idiosyncratic or 'stochastic' risks, where the probability of an adverse event (in this context, a loss of earnings) can be estimated. Actuaries can calculate the

\footnotetext{
${ }^{4}$ This has relevance for the design of social policy. A subsidy scheme, or any scheme that imposes behavioural conditionality, necessarily imposes what psychologists call "cognitive taxes" on the insecure person. Queuing, filling out forms, preparing for and undergoing intrusive inquisitive interviews, deciphering new rules or trying to respond to stigmatising demands, all represent taxes on the capabilities of those under stress.

${ }^{5}$ This is related to a famous article by Michael Lipton (1968).
} 
This is the accepted version of an article published by De Gruyter in Basic Income Studies 10 (2), 193-223, final version available at: http://www.degruyter.com/abstract/j/bis.2015.10.issue-2/bis-2015-0021/bis-2015-0021.xml Accepted Version downloaded from SOAS Research Online: http://eprints.soas.ac.uk/23032/

probability of illness, unemployment, pregnancy, injury and so on, allowing governments to devise contributory rules for social insurance schemes. ${ }^{6}$

In the context of the Indian study, besides contingency risks, risk can be divided into entrepreneurial and dependency risk. Entrepreneurial risk arises from attempts to increase income or production. Dependency risk arises from borrowing to acquire an asset or to pay for consumption that involves an obligation to repay the debt in the form of labour or to sell the resultant output only to the lender.

Dependency risk is pervasive in Indian villages. It is impoverishing and leads to debt bondage, in which borrowers are locked into quasi-permanent debt relationships dominated by the lender, who can determine when, where, and how much labour will be performed, and what the wage will be. As the single (monopsony) buyer of the debtor's labour, the lender can set a price (wage) below the prevailing market price of labour. Labour demand is seasonal, and at harvest time the market wage is well above its level in the slack season. So, landlords use debt to obtain labour for the harvest at below the market wage.

We should further distinguish between hazards, shocks and uncertainty, and between the probability of an adverse outcome, the probability of being able to cope with adverse outcomes if they arise, and the probability of being able to recover from them.

A hazard is a life-cycle event that in itself may be desired, but which is costly, such as the birth of a child, a marriage, or a family or community celebration. One reason for money being a contrived scarce commodity in Indian villages is the culturally institutionalised high cost of hazards such as weddings and births. They are major events.

A shock is an event that hits or affects whole communities or households. It may initially hit one person, but the costs spread and may threaten the livelihoods of others. Typical shocks are harvest failure, drought, and floods.

Uncertainty can be described as "unknown unknowns", for which it is not possible to calculate the probability of an adverse event occurring, the cost of the impact, the cost of coping or the cost of recovering.

A feature of the globalisation era is that everywhere more people are exposed to more shocks and hazards that cause more difficulty in coping and recovering from them. Globally, more people are fragile or less resilient (Taleb, 2012). And for many, the main form of insecurity is uncertainty, which by definition cannot be insured against.

We can hypothesise that a basic income, by providing basic security, would:

- Increase entrepreneurial risk-taking, because it would help assure the means to cope, and the means to recover, should the venture fail;

\footnotetext{
${ }^{6}$ Welfare states ran into a legitimation crisis when social insurance systems came under strain because different socio-economic groups had very different probabilities of needing benefits. The social insurance system could only function properly when contributions roughly equalled the demands for compensatory benefits.
} 
This is the accepted version of an article published by De Gruyter in Basic Income Studies 10 (2), 193-223, final version available at: http://www.degruyter.com/abstract/j/bis.2015.10.issue-2/bis-2015-0021/bis-2015-0021.xml

Accepted Version downloaded from SOAS Research Online: http://eprints.soas.ac.uk/23032/

- Reduce dependency risk-taking, by reducing the need to borrow and by increasing the pool of lenders, reducing reliance on monopsony lenders;

- Strengthen personal, family and community resilience, since fragility is associated with income insecurity.

\section{The Scourge of Debt}

Most Indian families struggle between debts; few are ever out of debt. Indebtedness is a structural feature of village life, and intensifies class and caste inequalities, preserving a hierarchical social structure. At the extreme are forms of debt bondage, whereby landlords or moneylenders put peasants into chronic debt, even over generations; they must spend most of their money to service their debt, and accept lower wages and more onerous labour than otherwise, so disrupting other earning activities.

The case studies from the pilot give a perspective. Consider Kalabai, aged 52, and her husband, from a scheduled caste, with a modest 1.5 bighas of land in a village where the basic income was paid:

My husband met with an accident ten years ago, and his right leg was seriously damaged. We spent 80,000 Rupees for his treatment. I borrowed from a moneylender at 3 per cent a month. I finally repaid it two years ago.

This debt stemmed from a shock. Over the eight years, that loan cost more than 100 per cent to repay. And their life of indebtedness persisted. As she added:

I had to borrow from a moneylender for my son's marriage one year ago, at 3 per cent a month. In addition, I often borrow for groceries or other necessities. I don't have to pay interest for that because I repay as soon as possible. I borrow about 700 Rupees a month. We repay debt by working for the moneylender or saving from our wage. Our labour is mostly for the repayment of loans, for which we work in the households of landlords because I have nothing to mortgage.

Just paying the 3 per cent a month, well over 40 per cent a year, would have been financially crippling. It is scarcely surprising that, once in serious debt, households remain in those circumstances for years, if not permanently.

Now consider Rajaram Sain, a 60-year-old man who combined being a barber with animal husbandry. He reported:

Each year the income is going down. It is mainly when there are deaths or other ceremonies in the village that my services are sought, for shaving heads. And for these services, the villagers pay me in kind, in wheat. The grain I get through this is hardly sufficient for the whole year... 
This is the accepted version of an article published by De Gruyter in Basic Income Studies 10 (2), 193-223, final version available at: http://www.degruyter.com/abstract/j/bis.2015.10.issue-2/bis-2015-0021/bis-2015-0021.xml Accepted Version downloaded from SOAS Research Online: http://eprints.soas.ac.uk/23032/

In the morning, after completing my barbering tasks, if any, I go to the field to get fodder and water for my buffaloes. I bought these buffaloes two years ago with a loan from the milk contractor from Indore. When I bought them, they were not giving milk. After they gave birth to calves four months ago, they started giving milk. Since then, I have been repaying the debt through milk. Every day, the contractor sends cans for collection of milk.

I owe the milk contractor money that I borrowed from him to purchase the buffaloes. I have another outstanding loan of 35,000 Rupees which I took for my daughter's wedding from my neighbour at 3 per cent interest rate, monthly. In addition to that, we buy food items from the grocery shop on credit at 2.5 per cent interest rate, monthly, and repay it by working on his farm. Brother, I have too many debts, and I can only repay them gradually, by selling milk and doing wage labour.

The barber's main transactions were non-monetary and almost certainly to his disadvantage, reducing their value. His customers were unlikely to give him their good-quality wheat and, since they could easily withdraw their custom, he would not be able to insist they did. By contrast, given the barber's weak bargaining position, the milk contractor could demand more milk than justified by the original loan. The barber was condemned to indebtedness, stretching into the future, in a structural system of rental income extraction.

Another example illustrates a widespread means by which moneylenders gain rental income from possessing the scarce commodity of money. Manju Behen told the case study team:

We take money from the milk contractor from Mhow in order to buy buffaloes and then we sell the milk to him only. We don't get any money from selling the milk because we first have to pay off the money that we took for buying the buffalo. If for some reason the buffalo does not give enough milk, then the seth [middleman] deducts the entire month's money... If we consume the milk at our homes or if we add too much water in the milk, then there is the risk of mounting debt... If we don't give the milk to the seth from whom we take money to buy the buffalo, then he takes the buffalo.

This exemplifies dependency risk, since acquisition of buffaloes was a survival strategy (Rosenzweig and Wolpin, 1993), not an entrepreneurial one, and illustrates the structural characteristic of "monopsony" debt. The moneylender retains sole right to the milk and can pay the indebted supplier below the market price, while imposing all the risks or costs on the debtor family.

Debt is a life-defining burden. Consider Premabai, a 60-year-old scheduled tribe woman, who mixed farming with agricultural wage labour over the course of the year:

I have about 1 lakh Rupees as an outstanding loan to be repaid at 3 per cent interest per month. I borrowed this amount for the treatment of my husband and grand-daughter from 
This is the accepted version of an article published by De Gruyter in Basic Income Studies 10 (2), 193-223, final version available at: http://www.degruyter.com/abstract/j/bis.2015.10.issue-2/bis-2015-0021/bis-2015-0021.xml

Accepted Version downloaded from SOAS Research Online: http://eprints.soas.ac.uk/23032/

neighbours. I also often borrow from our village grocery shop because he doesn't take interest. Sometimes I buy ration on credit. I work at the moneylender's houses or fields to repay the loan. All members of my family work to repay the loan. I have nothing mortgaged, but I have not been able to save anything.

Another example was Devkanyabai, a 45-year-old woman from the Chamar scheduled subcaste, who described herself as a labourer:

If we have money, then we buy our groceries in cash; otherwise we buy on credit. There are two shops in the village... from where we buy things on credit. We pay them back whenever we have money. They sell stuff at a hiked price - 9 Rupees if we pay cash, 13 if we buy on credit - because we have no other option but to buy from them. When we are in need of money, we must take a loan from the big farmers in the village. They charge an interest rate of 3 per cent. We remove these debts by doing labour work for them every crop season.

This is "monopsony" credit, taking advantage of villagers' need to live by credit. As well as indicating the scale of debt through high interest rates, this example shows the high cost of depending on credit rather than paying in cash. Often families cannot begin to repay the credit until the next harvest, meaning the cost accumulates month after month.

Villagers able to borrow from the nationalised banks or the SEWA Cooperative were charged much lower rates of interest than the rates demanded by moneylenders, indicating the advantage of financial inclusion. But this did not significantly alter the pattern of chronic debt.

In sum, debt in Madhya Pradesh villages mainly arises in five ways:

- Landlords and moneylenders provide loans to earn high rental income, usually lending at 3,5 , or up to 10 per cent a month, rarely less. They can do so because families do not have liquidity or other sources of credit.

- Large-scale farmers and business operators advance loans or provide low-income families with food or agricultural inputs at times of acute need, in order to put the individual or family into debt bondage, often with the obligation to provide part of or even all of the crop during or at the end of the harvest.

- They do such lending in order to oblige the family to provide labour as and when required for a wage that is less than a market wage, a form of "super-exploitation".

- Shopkeepers sell goods on credit, charging high interest after a month of non-payment. Some credit providers demand that purchasers provide labour or crops in return.

- Landowners or moneylenders lend for medical emergencies or for hazards such as marriages, taking land or jewellery as security, so that families lose their only assets when they cannot repay the loan, and are obliged to borrow at even higher interest rates at the time of the next crisis. 
This is the accepted version of an article published by De Gruyter in Basic Income Studies 10 (2), 193-223, final version available at: http://www.degruyter.com/abstract/j/bis.2015.10.issue-2/bis-2015-0021/bis-2015-0021.xml

Accepted Version downloaded from SOAS Research Online: http://eprints.soas.ac.uk/23032/

\section{How Basic Income Affects Debt}

Pervasive indebtedness was brought out in the evaluation surveys. Well over 70 per cent of all households reported being in debt. The basic income made a difference quite quickly.

In the 20 non-tribal villages overall, by the time of the Interim Evaluation Survey (IES), over half of all households reported that debt had increased over the past 12 months and only 8 per cent had reduced it. But basic income households were significantly less likely to have increased debt and were significantly more likely to have reduced it. Whereas two-thirds of control village households had increased debt, only 46 per cent of basic income households had done so. About 14 per cent of basic income households had reduced debt compared with just 3 per cent of the control households.

These results were sustained. The Final Evaluation Survey (FES) showed that, although over three-quarters of all households owed money to outsiders, this was significantly less common in basic income households - just over 71 per cent compared to 79 per cent in control villages. And the probability of having reduced debt in the period was considerably greater in the basic income villages.

Whereas 12.5 per cent of basic income households had reduced debt, only 4.6 per cent of control village households had. And whereas 4.6 per cent of the former had increased debt, over 58 per cent of control households had done so. The average amount owed was also lower in basic income households. And nearly two-thirds of those reducing debt attributed that to the basic income.

Among both low-educated and higher-educated households, the basic income was associated with a lower probability of being in debt. To make more sense of these correlations, a logit function was estimated, in which the dependent variable was the probability of having reduced debt (expressed as a binary, 1, for reducing debt, 0 otherwise). The function included control variables for caste, household size, land ownership, SEWA presence, female headship, education of household head, disability, and child-to-adult ratio.

The results (Table 1) showed that basic income households were significantly more likely to have reduced debt. Although a more refined model might bring out the significance of other factors, this points to a direct positive link between basic income and debt reduction.

Table 1: Probability of Debt Reduction, by Type of Household, FES, 2012

\begin{tabular}{|c|c|c|c|}
\hline & I & II & III \\
\hline VARIABLES & Reduced Debt & Reduced Debt & Reduced Debt \\
\hline & All & OBC/Gen & SC/ST \\
\hline Upper Caste & 0.043 & & \\
\hline
\end{tabular}


This is the accepted version of an article published by De Gruyter in Basic Income Studies 10 (2), 193-223, final version available at: http://www.degruyter.com/abstract/j/bis.2015.10.issue-2/bis-2015-0021/bis-2015-0021.xml Accepted Version downloaded from SOAS Research Online: http://eprints.soas.ac.uk/23032/

\begin{tabular}{|c|c|c|c|}
\hline Head's Education & 0.164 & 0.013 & 0.43 \\
\hline Disabled & -0.455 & -0.55 & -0.348 \\
\hline Female Head & 0.111 & 0.171 & -0.027 \\
\hline Child Ratio & 0.001 & 0.001 & 0 \\
\hline Household Size & $0.057^{*}$ & $0.069 *$ & 0.018 \\
\hline SEWA Village & -0.065 & 0.081 & -0.337 \\
\hline Basic Income & $1.210 * * *$ & $1.243^{* * *}$ & $1.195^{* * *}$ \\
\hline Own Land & $-0.316^{*}$ & -0.23 & -0.443 \\
\hline Constant & $-3.062 * * *$ & $-3.288 * * *$ & $-2.617 * * *$ \\
\hline No. of observations & 1,665 & 1,068 & 597 \\
\hline Pseudo R-squared & 0.0529 & 0.0563 & 0.0549 \\
\hline \multicolumn{4}{|c|}{$* * * p<0.01, * * p<0.05, * p<0.1$} \\
\hline
\end{tabular}

Note: OBC: Other Backward Castes; Gen: General; SC/ST: Scheduled Caste/Tribe.

Drawing on the case studies and the statistical data, we can conclude that the basic income reduced debt in five ways:

- By being used to reduce previously incurred debt.

- By enabling households to avoid incurring new debt or to reduce its amount.

- By enabling households to avoid taking food or other items on credit.

- By inducing moneylenders or shops to advance credit or loans at a lower interest rate or even without charging interest.

- By enabling the poorest households to borrow softer loans from relatives or friends, rather than resorting to exploitative forms of distress borrowing.

The last two are easily overlooked. In an economy characterised by scarce money, one way by which a basic income reduces the cost of living is by increasing lenders' confidence that they will be repaid, meriting a lower interest rate due to the lower risk of non-reimbursement. This was brought out by a case-study respondent interviewed several months after the pilot had ended:

When the transfers [basic income] were coming, the moneylending farmers were also sure their money would be paid on time. They would lend us money without too much interest. Now the money has stopped, the farmers are charging 5 per cent or 10 per cent. If you 
This is the accepted version of an article published by De Gruyter in Basic Income Studies 10 (2), 193-223, final version available at: http://www.degruyter.com/abstract/j/bis.2015.10.issue-2/bis-2015-0021/bis-2015-0021.xml

Accepted Version downloaded from SOAS Research Online: http://eprints.soas.ac.uk/23032/

start giving the money again, then give it like before. Don't give it via the village sarpanch [headman] or ministers.

Others described how they used the basic income to reduce debt. Thus Sunita, a 28-year-old woman who combined housework as her main activity with casual wage labour, said:

We have no debts of any kind on us anymore. We had a little bit of debt to pay; I don't know how much it was; my brother-in-law knows. Whatever it was, we paid it back this year; and this has happened with the help of the cash transfers.

Another, Pratap, a 35-year-old chowkidaar (village headman), told the enumeration team:

The cash transfers have helped us immensely. We have put more and good quality seed, fertilizer and pesticide in the fields due to this money. This will yield us a better crop. Apart from that, we bought two goats to add to our income. The most important benefit from this money was that we didn't have to borrow money from anyone, and neither did we have to buy things on credit. Earlier we had to do both. We have paid back whatever petty debts were there; 500 to someone and 1,000 to someone else. And due to this money, our monthly grocery and foodstuffs were bought in an organised manner; otherwise we had to buy lesser stuff.

Another respondent told the team:

Because of this money we don't have to take any debt for either rations or medicines. Even if someone gets sick or distressed, we don't have to go around begging people for money. Earlier we would take things on credit from the Kirana [ration] store, for which the shopkeeper would charge us interest as well.

Another was almost poetic:

Some time ago, I took 2,000 Rupees on credit from the Kirana shop and bought things for the household from there, little by little. Within a year, the shop-owner brought my credit amount to 24,700 Rupees after adding the interest. In order to pay this debt I had to mortgage the one bigha given to me by the government. Now I am left with no land. Our monthly expenses are covered by this cash transfer we are getting. This money is to us like a stick is to a blind man.

In the tribal villages, debt was even more just a regrettable way of life for most families, with over two-thirds in debt when the pilot started. As labour opportunities were meagre and incomes low, almost every aspect of their lives was governed by debt. They borrow for seeds and farming inputs, and must repay those debts at 100 per cent interest after the following harvest. They must also borrow to pay for daily or weekly food purchases.

However, the basic income made a difference there too, and liberated some from the debt burden. In the basic income village, by comparison with the control village, within six months many had reduced debt and many fewer had avoided going into more debt. By the end of the pilot, as shown in the FES, an extraordinary 73 per cent of households in the basic 
This is the accepted version of an article published by De Gruyter in Basic Income Studies 10 (2), 193-223, final version available at: http://www.degruyter.com/abstract/j/bis.2015.10.issue-2/bis-2015-0021/bis-2015-0021.xml

Accepted Version downloaded from SOAS Research Online: http://eprints.soas.ac.uk/23032/

income village had reduced debt, and none had increased it. By contrast, 18 per cent of the control village households had reduced debt, and 50 per cent had increased it.

In sum, in both the general and tribal villages, the basic income lessened indebtedness. In doing so, it lessened the pressure on daily living, and enabled some households to gain more freedom to pursue other economic activities, in their own interest.

\section{Combating Debt Bondage}

In Madhya Pradesh villages, indebtedness also plays a central role in the social relations of production and distribution through a form of debt bondage known as the naukar (servant), by which men "voluntarily" enter an annual contract with a landlord to labour as and when required in return for an initial loan. If a boy enters such a contract, it is known as a gwala (cowherd) relationship, because the main labour of boys is caring for cattle.

Often, as probably intended by the landlord, the naukar or gwala cannot pay off the debt and this is rolled over and built up over years, even generations. A naukar can change landlord only after the debt has been repaid, but otherwise must do all labour assigned to him by the landlord; the type, extent and timing of labour is at the landlord's discretion.

Several case studies illustrated the debt bondage that the naukar system represents. Gumaan Singh, a 55-year-old landless member of a scheduled tribe, told the enumerators:

We require about 7 quintals of wheat each year for home consumption. We collect this wheat by doing labour during the wheat harvest. All adult members in the family do labour. I used to work as a bonded labourer until last year, for which I received 18,000 Rupees annually. I have been a naukar with the landlords in our village for nearly 35 years. I have stopped doing that now...

From morning till night, I used to work on the landlord's farm and also looked after his buffaloes. Except cooking, I did everything for him. He did not provide food. I had to come home to have my roti, and go back to work. From time to time, I would borrow money from him for my daily needs, or when I would go to the weekly market, which he used to deduct from the wage. Last year, at the time of my daughter's marriage, I asked him for money, but he gave me only 10,000 Rupees. I was very disappointed, and when I completed half a year in November, I quit. After that I started doing daily wage work wherever and whenever I could...

We were greatly helped by the basic income money. If we didn't get any labour, then we didn't have to think about where to get food from. We could go to the doctor for treatment whenever required...If it weren't for this money, then perhaps I'd still be working as a bonded labourer.

This family pooled their monthly basic incomes to buy Gumaan out of bonded labour, emancipation in the most literal sense. 
This is the accepted version of an article published by De Gruyter in Basic Income Studies 10 (2), 193-223, final version available at: http://www.degruyter.com/abstract/j/bis.2015.10.issue-2/bis-2015-0021/bis-2015-0021.xml

Accepted Version downloaded from SOAS Research Online: http://eprints.soas.ac.uk/23032/

Another naukar, Paramanand, a 19-year-old Bhil, was supposed to be paid an annual wage, from which he received an advance as a loan. But over the year he was obliged to take additional small loans from the landlord, enmeshing him in a web of debt. He ended up having to labour to pay back a stream of loans; he never saw any cash. During the pilot, he too managed to buy his freedom.

Another case was described by a mother whose two elder sons were in debt bondage:

My elder son [Vinod, aged 17] is a naukar at 15,000 Rupees per year and the younger son [Lakshman] at 10,000 Rupees a year. My husband does casual labour. The children go to their malik [master] early in the morning and return in the evening. Vinod takes care of the cattle along with doing farming work; Lakshman only does the job of herding cattle at their malik's residence. They don't let these children come home for lunch and feed them there so that they can save time to extract more work from them.

The landlord benefits doubly from having a naukar. Not only can he pay little or nothing, rather than a market wage, he can also demand labour when he requires. In return, the naukar receives from the malik some "food security", but at best receives only a minimal amount of money, as a loan. Some villagers reported that such loans spanned twelve years.

Although the evaluation surveys could not reveal the extent of debt bondage, since the questions on main and second main economic activities focused on activities rather than on the motivation for doing them, they did reveal the impact of basic income on the naukar phenomenon. The FES asked whether any household member did labour to pay off debt and whether they had been doing so a year earlier. By the end of the pilot, a significantly smaller share of basic income households had someone labouring to pay off debt. And among families that had been in a naukar relationship, significantly more basic income households had managed to end it.

The loss of freedom entailed by the naukar system has two negative effects on income: directly, because someone locked into a labour relation in advance will receive a lower wage than if they could bargain with a landlord employer when they are required; and indirectly, because the obligation to labour during the harvest season, for instance, limits the time and effort that can be devoted to other waged activities or own production.

Thus the basic income is emancipatory in the following ways:

- It leads to some escape from naukar bonded labour;

- It reduces pressure for "super-exploitation", that is, the obligation to accept a wage below the market wage, due to already incurred debt and perhaps an anticipated need to borrow from the employer in the future, accepting the lower wage being an implicit form of insurance.

\section{Borrowing and Basic Income}


This is the accepted version of an article published by De Gruyter in Basic Income Studies 10 (2), 193-223, final version available at: http://www.degruyter.com/abstract/j/bis.2015.10.issue-2/bis-2015-0021/bis-2015-0021.xml Accepted Version downloaded from SOAS Research Online: http://eprints.soas.ac.uk/23032/

Borrowing and indebtedness are not the same. Many people borrow to deal with emergencies, when money "sharks" can take advantage of their vulnerability to charge high interest rates and impose arduous conditions, often demanding the mortgage of something they can ill afford to lose. They then fall into chronic debt that erodes their capacity to survive or escape income poverty.

Some households also borrow to try to raise income or production. Borrowing by the rich is mainly to expand; borrowing by the poor is to survive. Yet the poor pay much higher interest rates than the rich. The money they borrow usually has a lower rate of return than is gained by the wealthy who can borrow strategically. Thus borrowing is a mechanism for increasing inequality. By deduction, anything that reduces the poor's need to borrow should have beneficial effects in terms of equity.

The FES suggested that, even after a year, there were on average no differences in borrowing habits between basic income and control households. But the former were significantly less likely to have borrowed for food, corresponding to evidence from case studies. Borrowing for housing was more common among basic income households, also backed up by case studies showing families using the basic income to make house improvements such as stouter roofs or toilets (Davala et al., 2015, ch.4).

Scheduled tribe households were the least likely to borrow for whatever purpose. When they did, borrowing was usually to meet daily needs. And, among those who did borrow, they were the least likely to borrow from institutional sources.

In the tribal villages, in order to detect shifts linked to the basic income, the evaluation surveys included questions on the main reason for borrowing. Comparing the borrowing by the difference-in-difference method, there was a significant reduction among basic income recipients in borrowing for normal living expenses and for medical expenses. In the control village, the proportion borrowing for regular living expenses rose from 20 per cent to 36 per cent during the course of the pilot, whereas in the basic income village it remained at 23 per cent. What declined most for basic income recipients was distress borrowing.

In the tribal villages, the most common reason for borrowing was for medical expenses. For small items, families generally borrowed from relatives or neighbours; for larger sums they resorted to moneylenders. But basic income households shifted from borrowing to relying on savings. At the outset, 44 per cent reported that borrowing was the main means of financing medical treatment; by the end only 19 per cent reported this. At the outset, 33 per cent relied mainly on savings; at the end 74 per cent did so. Meanwhile, in the control village, the share relying on saving rose from 47 per cent to 54 per cent, while the share relying on borrowing remained roughly the same, as did reliance on assistance from relatives.

However one interprets these shifts, the basic income allowed families to reduce their need to borrow, in circumstances where borrowing has traditionally been a route into chronic debt.

\section{The Impact on Saving}


As India has no comprehensive social security system, saving is the main means by which families try to protect themselves against the vagaries of life, in the form of cash saved at home, gold or silver, money in a post office or bank, or investment in land or other property.

In villages covered by the pilots, even though debt was pervasive, some households did manage to save money, and the basic income increased that proportion significantly. Even by the time of the IES, those who had received the basic income were much more likely to be saving. And there appeared to be a positive influence of both the basic income and SEWA. Over 51 per cent of households in the SEWA basic income villages had savings by then, compared with 38 per cent of non-SEWA counterparts. By contrast, in the control villages, just 16 per cent of SEWA and 11 per cent of non-SEWA households had any savings. Both the SEWA and basic income differences were statistically highly significant.

In the FES, however, although the impact of the basic income remained significant, the SEWA correlation only held within the basic income villages (23 per cent in SEWA versus 18 per cent saving in the non-SEWA villages). By then, the difference in savings between the basic income and control villages was even greater. In the former, 20.5 per cent were making savings compared with just 9 per cent in the control villages.

Of course, many factors influence savings behaviour. Accordingly, using FES data, logit functions were estimated in which the dependent variable was the probability of saving, expressed as a binary ( 1 if saved; 0 if not), with similar control variables as in the debt reduction function reported earlier. Table 2 shows clearly that, controlling for the possible influence of other factors, receipt of the basic income was associated with an increase in saving. This applied to the lower-income scheduled tribe and caste households as for others. Also statistically significant as influencing the propensity to save were the schooling of the head, landholding, caste of households, and household size. The presence of SEWA was linked to more saving by the scheduled tribe and caste households but was not significant for richer groups.

Table 2: Probability of saving, by Type of Household, FES, 2012

\begin{tabular}{|c|c|c|c|}
\hline & I & II & III \\
\hline VARIABLES & Saving & Saving & Saving \\
\hline Upper Caste & All & OBC/Gen & SC/ST \\
\hline Head's Education & $0.412^{* * *}$ & & \\
\hline Disabled & $0.376^{* *}$ & 0.252 & $0.680^{*}$ \\
\hline Female Head & -0.278 & -0.335 & -0.052 \\
\hline Child Ratio & $0.374^{*}$ & 0.29 & 0.497 \\
\hline
\end{tabular}


This is the accepted version of an article published by De Gruyter in Basic Income Studies 10 (2), 193-223, final version available at: http://www.degruyter.com/abstract/j/bis.2015.10.issue-2/bis-2015-0021/bis-2015-0021.xml Accepted Version downloaded from SOAS Research Online: http://eprints.soas.ac.uk/23032/

\begin{tabular}{|c|c|c|c|}
\hline Household Size & $0.045^{*}$ & $0.057 * *$ & -0.013 \\
\hline SEWA Village & 0.086 & -0.049 & $0.454 *$ \\
\hline Basic Income & $0.871 * * *$ & $0.839 * * *$ & $1.000 * * *$ \\
\hline Own Land & $0.398 * * *$ & $0.449 * *$ & 0.248 \\
\hline Constant & $-3.082 * * *$ & $-2.767 * * *$ & $-2.893 * * *$ \\
\hline No. of observations & 2,022 & 1,294 & 728 \\
\hline Pseudo R-squared & 0.0562 & 0.0432 & 0.0646 \\
\hline \multicolumn{4}{|c|}{ Significance: ${ }^{* * *} \mathrm{p}<0.01,{ }^{* *} \mathrm{p}<0.05, * \mathrm{p}<0.1$} \\
\hline
\end{tabular}

Note: OBC: Other Backward Castes; Gen: General; SC/ST: Scheduled Caste/Tribe.

In terms of saving from the basic income itself, the FES found that the average amount was higher in non-SEWA (694 Rupees) than in SEWA households (586 Rupees). This may have been because it was easier for women to withdraw money from the SEWA Cooperative (which visited the villages from time to time) than from a bank, so that SEWA women were more inclined to use the basic income for daily needs.

The pattern in the tribal villages was similar, although there were slight differences. Tribal families tend to have lower incomes and living standards, most living a hand-to-mouth existence, having to borrow even for their everyday needs. Nevertheless, the basic income induced more households to save. The share that saved money in the control village actually declined from 9 per cent at the outset to 3 per cent in the FES, whereas in the basic income village the share rose from 7 per cent to 25 per cent. Clearly, the saving propensity was much higher in the basic income village.

In sum, the basic income enabled at least some families to save, obtaining financial liquidity needed to gain a modicum of control over their lives.

\section{Forms of Saving}

In India, the most common forms of savings are keeping cash in the home and purchasing gold or jewellery. One might anticipate that the basic income would induce households to shift from the former to saving in a bank or cooperative, especially since the basic income was paid into bank accounts. And indeed, after a few months, according to the IES, basic income recipients were much more likely to be saving in a bank than at home; only about 9 per cent were keeping savings at home compared with over 41 per cent of savers not receiving the basic income. 
This is the accepted version of an article published by De Gruyter in Basic Income Studies 10 (2), 193-223, final version available at: http://www.degruyter.com/abstract/j/bis.2015.10.issue-2/bis-2015-0021/bis-2015-0021.xml

Accepted Version downloaded from SOAS Research Online: http://eprints.soas.ac.uk/23032/

The FES also asked about the form of saving from the basic income alone, and what institutions were used for saving from any source. Just over half (52 per cent) of those who saved from the basic income did so mainly in bank accounts, while 40 per cent did so mainly in their homes. According to the broader question, among basic income households who saved, 53 per cent saved mainly in a bank, compared to just 30 per cent of control village households.

Note that the second question asked if households saved in any institution, whereas the question on saving from the basic income asked for the main place of saving. So, for instance, 15 per cent of basic income recipients said they saved some money in their homes, compared with 39 per cent of those who saved among control households.

If we accept that savings in banks are more secure than keeping cash at home, and so more valuable, we see that the basic income boosted savings directly, through providing more money, and indirectly, through inducing so-called "financial inclusion".

An objective of the drive for financial inclusion is to bring individuals into the financial system, so they can save and borrow more effectively. Now consider the change in savings behaviour in the basic income tribal village during the pilot. In the baseline survey, 38 per cent of households that were saving were doing so mainly in a bank, the remainder at home. By the time of the FES, 30 per cent were saving in the bank, 20 per cent were saving in the SEWA Cooperative, and only 50 per cent were keeping savings at home. This shift towards institutional saving was probably due in part to the active role taken by the SEWA Cooperative.

In brief, as financial securitisation is desirable for the struggle against poverty and economic insecurity, the effect of the combination of basic income and SEWA further testifies to the emancipatory value of a basic income.

\section{Intended Uses of Savings}

In the FES, households that were saving were asked about their reasons for doing so. In the general village pilot, the main response was "keep for security" (60 per cent), followed by "nothing in particular" (30 per cent). With 5 per cent saying "don't know", we can see that overwhelmingly the primary rationale was to gain liquidity in case of sudden need. Apart from that, the most common reason given for saving was for illnesses and medical treatment. A typical situation was that of Radhabai, a Bhil caste woman, aged 30, who was mainly a wage labourer. She put it as follows:

Having spent the first few cash transfers on clothes and an ox, the family started to save from them in order to cover for possible illnesses, after several bouts of sickness.

Having financial liquidity is essential in circumstances characterized by uncertainty, where at any time unforeseen needs could arise. Without ready money, households easily fall into the hands of moneylenders. 
This is the accepted version of an article published by De Gruyter in Basic Income Studies 10 (2), 193-223, final version available at: http://www.degruyter.com/abstract/j/bis.2015.10.issue-2/bis-2015-0021/bis-2015-0021.xml

Accepted Version downloaded from SOAS Research Online: http://eprints.soas.ac.uk/23032/

Rural households may see different sources of income differently. Some sources may be regarded as for daily, weekly and monthly needs, whereas a basic income may be regarded more as a source of security. This may apply even though money is fungible. But the key point is that financial liquidity represents security.

In the tribal villages too, most households that saved reported that they did so primarily for security and for investing in income-generating activities. Some said they had no specific reason, which can also be interpreted as for security. As medical emergencies were what people most feared, part of what they called "security" probably meant this.

However, during the pilot, there was a shift in thinking about the purpose of saving, as more came to use it for investment in livestock, fertilisers and other agricultural inputs. In the IES, 62 per cent reported that they were saving for security, 3 per cent for purchasing animals, and 28 per cent for "no specific reason". By the time of the FES, 47 per cent reported that they kept savings mainly for security. Those who were saving to buy animals or fertilizers had risen to 13 per cent. This may have reflected the improvement in the local economy due to the basic income itself. Confidence breeds entrepreneurial instincts of the better kind.

\section{The Odd Couple: Debt and Saving}

It might be presumed that if a household had substantial debt it would use any extra cash to reduce it. But, in a low-income area, financial liquidity is a basic need. Families want liquidity, especially for unanticipated demands such as illness, when they need to pay for a visit to the doctor or to buy medicine. There are also strong incentives to reduce debt as well since, as shown earlier, most households must pay high rates of interest.

The result was that families tried to do both. Thus, in the general villages, according to the FES, 69 per cent of households that had made savings in the previous 12 months also had substantial unpaid debt. Of those with debt, 13 per cent reported making savings, compared with 18 per cent of those households with no debt. That difference was statistically significant, indicating how debts and savings coincided.

Among indebted households, those with the basic income had a significantly higher propensity to save (19 per cent, compared with 11 per cent of control households). The results were similar in the IES and FES. They further testify to the positive effect of basic income on savings.

\section{Hazards and Shocks}

Most households in rural India experience socio-economic shocks (sudden events that threaten them financially and materially) and hazards (life-cycle events that cause financial stress). More should be done to reduce the obligatory costs imposed on low-income households by hazards, as already recognised by the Madhya Pradesh government, which gives financial support for group weddings under the Mukhyamantri Kanyadan Yojana. But both hazards and shocks remain very costly. 
This is the accepted version of an article published by De Gruyter in Basic Income Studies 10 (2), 193-223, final version available at: http://www.degruyter.com/abstract/j/bis.2015.10.issue-2/bis-2015-0021/bis-2015-0021.xml Accepted Version downloaded from SOAS Research Online: http://eprints.soas.ac.uk/23032/

Box 1 presents a rough division of shocks and life-cycle hazards. Recall that often a hazard is something that is welcomed, whereas a shock is not, however much it might be anticipated.

\section{Box 1: Causes of financial crises: Shocks and Life-cycle Hazards}

\begin{tabular}{|c|c|}
\hline Shocks & Life-Cycle Hazard \\
\hline Death of child & Birth of child \\
\hline Medical costs & Marriage costs \\
\hline Crop failure & $\begin{array}{l}\text { Cost of weddings, funerals, other } \\
\text { ceremonies and feasts }\end{array}$ \\
\hline $\begin{array}{l}\text { Rising price of goods needed for trade, } \\
\text { business or farming }\end{array}$ & Repayment of loans/debt \\
\hline Loss of job & Children's schooling \\
\hline \multicolumn{2}{|l|}{ Death of income earner } \\
\hline \multicolumn{2}{|l|}{$\begin{array}{l}\text { Lost income due to insufficient demand for } \\
\text { products }\end{array}$} \\
\hline \multicolumn{2}{|l|}{ Loss of work due to illness or injury } \\
\hline \multicolumn{2}{|l|}{ Natural disaster (flood, drought, etc.) } \\
\hline Ejection or threatened ejection from house & \\
\hline Child stopping work for family & \\
\hline
\end{tabular}

The FES contained a module of questions on shocks, hazards and financial crises experienced by households. Although shocks and hazards may be random, due to events that have nothing to do with the basic income, we may hypothesise that the basic income both lowers the probability that such events will entail a subsequent financial crisis and increases resilience the ability to weather a crisis and recover from it.

A first question asked in the survey was whether there had been a financial crisis in the past 12 months. In the general villages, 48 per cent of all households reported having experienced at least one financial crisis. There was no apparent difference by whether or not they had received the basic income, as shown in a logit function in which household characteristics and assets were taken into account. Although a crisis was more likely in households containing someone with a disability, or if there were more children, in most respects the probability of a crisis was random. However, the basic income did make a difference in increasing resilience.

Take the situation of Ramkanya, a 40-year-old woman from a scheduled caste, with a small plot of land, having to support a mentally disabled husband and three adolescent children:

From my cash transfer account, I took out 1,000 Rupees in bulk when in one week there were two weddings in my husband's family....Also, when the ration shop suddenly provided rations for six months, I had to purchase 1 quintal and 16 kilos of wheat, 5 litres of kerosene and 7 kilos of rice at one go. I had to pay 560 Rupees. I used the cash transfer money for that. 
This is the accepted version of an article published by De Gruyter in Basic Income Studies 10 (2), 193-223, final version available at: http://www.degruyter.com/abstract/j/bis.2015.10.issue-2/bis-2015-0021/bis-2015-0021.xml

Accepted Version downloaded from SOAS Research Online: http://eprints.soas.ac.uk/23032/

Without a basic income, her options would have been to incur a debt or to do without the rations. Now consider Ramesh, a 45-year-old whose main activities were farm labour and own-account farming. He experienced a shock induced, ironically, by a government subsidy scheme and the uncertainties of agricultural prices:

I had sowed a garden of papaya in one bigha of my land during the Holi season [March]. The government provided these plants, fertilizers and pesticides. Other than that, we were given 2,000-3,000 Rupees for the labour on the papaya field through 'job card'. We suffered a loss of two crops by sowing papaya, wheat and soya. We get two sacks of soybean from this land, which sell for 6,000 Rupees, and five sacks of wheat, which means we lost 11,000-12,000 Rupees. Other than this, I had planted chilli among the papaya plants. But it didn't grow because of shade from the papaya plants. So, 2,000 Rupees were spent in its removal...

One seth [middleman] came from outside to buy our papaya, paying 3-4 Rupees per kilogram. He has not returned, because the market price for papaya is low this year. We did a lot of hard work for this crop, but have suffered a huge loss due to the low market price. I will never grow papaya again...The bank people came some time back and were asking for the money. They told us that if we didn't pay back the money, they would have our land auctioned.

Here was somebody struggling to overcome setbacks caused by an ill thought-out subsidy scheme that had produced a negative shock. ${ }^{7}$ The scheme's designers were inadvertently responsible for the financial crisis. To compound it, Ramesh had to deal with a hazard:

This year, as well as suffering a lot of damage due to the papaya crop, I also have had to marry off my three children, one daughter and two sons. For the sons we shall have to give 30,000 Rupees to the bride's side and we'll have to put aside some money for our daughter...I will have to borrow money on interest from some moneylender. This year the crop is also not flourishing because of the pond water being cold. There is also a tradition in our community of giving seven kitchen utensils for the daughter's wedding.

Since the distribution of this money [basic income], the villagers have started to give 100 Rupees from each house to the family in which there is a marriage. A total of 10,000 Rupees is collected from the whole village. This money is enough at least to pay the food expenses in the marriage. This is support from the villagers.

Here was a collective response to individual hazards, made possible by the basic income. It is about asserting some control over sources of economic insecurity, an unanticipated outcome of the basic income pilot indicative of enhanced social solidarity. Before the basic income started, the tradition had been to contribute just 10 or 20 Rupees per household to a village marriage.

\footnotetext{
${ }^{7}$ There should always be scepticism about the intentions of selective subsidies. Commercial interests may be behind them.
} 
This is the accepted version of an article published by De Gruyter in Basic Income Studies 10 (2), 193-223, final version available at: http://www.degruyter.com/abstract/j/bis.2015.10.issue-2/bis-2015-0021/bis-2015-0021.xml

Accepted Version downloaded from SOAS Research Online: http://eprints.soas.ac.uk/23032/

Now reflect on a shock that can have devastating consequences. Chandaben, a 45-year-old Balai caste woman whose main occupation was labouring, told our team:

My husband was sick for nearly two years. He passed away recently. He had acquired this disease where his whole body had swollen up. We got him admitted to the private hospital in Indore. He was there for 15 days but we were not able to afford further treatment. Finally, we managed to borrow 40,000-50,000 Rupees from relatives. After spending that on treatment we had to admit him to the government hospital in Indore. He stayed there for a month but no improvement was shown. We had no money to get him admitted to a private hospital. His condition kept deteriorating and within a month he expired.

After that, all responsibility of the household came to me. He used to earn about 24,000 Rupees a year by working as a domestic in some household. After his demise, I and my son Narendra increased our hours of labour but one of my sons is mentally challenged so is unable to do much labour. He is easily exploited by employers. Three of my boys are studying and we have to bear the expenditure for their education.

.....We borrowed money for my husband's treatment. And my husband had also borrowed money for our daughter's wedding. After that, we have also borrowed small amounts...I do not know how I am going to repay my debt.

The basic income money is spent on food items only. The intake of food has increased a little ever since we started receiving it. We have been able to buy provisions on time. We get basic income money for five members in my family. Since my son is mentally challenged, his money is also credited to my account. This money has helped a lot. If it were not for it, we would have had to send our children for labour work. But because of this money we were able to send them to school.

While the basic income did not enable this family to overcome its debt, it helped it cope by providing the means of obtaining food during the crisis. Regardless of whether people experience a shock or a hazard, the most crucial issue is how they cope and recover.

As noted earlier, economic insecurity makes people more cautious and less entrepreneurial, to their longer-term financial disadvantage. If fewer households in a community have a crisis from which they cannot recover, the community benefits by becoming more entrepreneurial, even among those who experienced crises (Knupfer et al., 2013). So, if a basic income improves the capacity to cope, that can have wider positive ramifications for the community as a whole.

Respondents who had experienced a crisis were asked what had been the main and secondary sources of financial support during their most serious crisis. Most did borrow, whether or not they had been receiving the basic income. However, the type of lender changed in basic income households. More could keep moneylenders at bay. Only 41 per cent of basic income households hit by a crisis resorted to them, compared to 54.5 per cent of control households. The universal nature of the basic income meant that in a crisis more families could turn to informal sources of support. 
This is the accepted version of an article published by De Gruyter in Basic Income Studies 10 (2), 193-223, final version available at: http://www.degruyter.com/abstract/j/bis.2015.10.issue-2/bis-2015-0021/bis-2015-0021.xml Accepted Version downloaded from SOAS Research Online: http://eprints.soas.ac.uk/23032/

A logit function was run to see if the basic income lowered the probability of a household hit by a financial crisis going to a moneylender. Those receiving a basic income had a significantly lower probability of resorting to one, further supporting the hypothesis that its full value exceeds the monetary value. Implicit in this finding is that the basic income lowers the cost of crises, because families can draw on the support of kin and neighbours, whether formally pooling money or providing money as and when needed.

A related issue is whether households hit by a financial crisis had to sell or mortgage assets. Some 10.5 per cent of those hit by a crisis resorted to this, but there was no difference by whether they received the basic income. In a logit function, the coefficient on basic income was not significant, although it was negative.

\section{Why the Emancipatory Value of Subsidised Food is less than its Monetary Value}

By contrast with what happens with a basic income, we can argue that the emancipatory value of a subsidised commodity, as epitomised by the Indian Public Distribution System (PDS), is less than the monetary value, for four reasons. First, by definition, a subsidy distorts relative prices, lowering the price of subsidised commodities and thus affecting the recipient's ability to choose between goods and services according to the perceived value for that person. Paternalistic subsidies are based on a presumption of knowing what people want and need, and they are limited to a narrow range of goods.

Second, providing subsidised goods involves high transaction and administrative costs, including the cost to the state of acquiring, storing and finally transporting the food in small quantities to the vast network of ration shops that is a feature of Indian rural life.

Third, the subsidy system involves unrecognised costs for the villagers, who have to use up time going to the ration shops, proving entitlement and queuing, often repeatedly, all of which reduce the value of the commodity. To that must be added the time cost of sifting the good grain or padi from the bad, a task that may remove the value of the subsidy altogether. In some of the survey villages, women had to sift subsidised grain for hours to separate the grain from stones put in to make up the weight.

Fourth, disbursement of subsidised grain by ration shops is uncertain, depending on the vagaries of supply and logistical problems. In some months, there were no deliveries in the survey villages; in others a short-lived surplus. Potential recipients were expected to have cash at the ready at short notice. For instance, in the rainy season of 2011, the State government suddenly decided it would disburse three months of rations in one month. Many households could not pay; many did not have suitable storage to keep the food in usable condition. Even worse, in the next rainy season, the government obliged households to pick up rations for six months in one go.

When such situations arise, low-income families must borrow money, or do without the subsidised food. When the government disbursed rations for six months, a BPL family had to have in hand Rs.1,295, while an Antyodaya family had to have Rs.1,070. Unable to obtain cash at short notice, most families had to borrow at very high interest rates. 
This is the accepted version of an article published by De Gruyter in Basic Income Studies 10 (2), 193-223, final version available at: http://www.degruyter.com/abstract/j/bis.2015.10.issue-2/bis-2015-0021/bis-2015-0021.xml Accepted Version downloaded from SOAS Research Online: http://eprints.soas.ac.uk/23032/

These shortcomings of subsidised goods are in addition to the well-known defects of the PDS - the diversion to private sales of up to 75 per cent of the items in question, and the deficiencies of the ration card system, which aims to target the poor but, like all targeting systems, does not do so effectively. This was confirmed in the survey villages, where numerous poor households either did not have ration cards or had the wrong one.

Extending the argument to all forms of subsidised goods, the amount spent on operating any subsidy vastly exceeds the monetary value received by the recipient. Even if the quality of the subsidised commodity was as good as the equivalent in the market, there is a value in having a choice of when, where and how much to buy. Indeed, the person may not want that commodity and may want something else. Moreover, a market operates on the basis of competition and bargaining, imposing pressure on providers to improve quality, and thus improve the use value of the goods in question.

\section{Reducing the power of landlords and moneylenders}

The landlord-moneylender class in Indian villages is an oligopoly. ${ }^{8}$ Its members are few in number, mostly related, and as a group they in effect sell "loans". They may thereby put villagers in debt bondage, or in seasonal debt traps, obliging the latter to sell their labour, and/or pay back money when required, to a sole buyer, on terms the moneylender-landlord can determine at his convenience.

By helping people to escape from bonded labour, basic income clearly has the potential to disrupt the social system that entrenches these practices, giving it a transformative role that subsidy or direct labour schemes cannot emulate.

More broadly, a basic income limits the moneylenders' oligopolistic power largely because it reduces the contrived scarcity of money in the community, the commodity that moneylenders or shopkeepers "sell". The basic income also reduces the monopsonist power of moneylenders. If the basic income is paid to all members of the community, others will have financial liquidity from which to lend to relations, friends or neighbours, and can also, if necessary, borrow small amounts from them, against their future basic income.

Moreover, if everybody in the community has a basic income, a lender has more assurance of being repaid, and thus can charge a lower interest rate to reflect the lower risk of nonpayment. This would be important at times of personal or family emergencies, when villagers' bargaining position is at its weakest. If, by contrast, cash transfers were meanstested or made conditional on specified behaviour, then the value of any income received would be less, simply because it would be uncertain. This would put upward pressure on the interest rate, the "price" of a loan, because the lender could not be sure that the transfer would be provided and thus that the person would be in a position to repay the loan.

Similarly, in a cash-scarce economy, offering goods on credit is a structural way of increasing the price, since after a short period of non-payment the purchaser must begin paying interest,

\footnotetext{
${ }^{8}$ An oligopolist is one of a small number of sellers.
} 
This is the accepted version of an article published by De Gruyter in Basic Income Studies 10 (2), 193-223, final version

available at: http://www.degruyter.com/abstract/j/bis.2015.10.issue-2/bis-2015-0021/bis-2015-0021.xml

Accepted Version downloaded from SOAS Research Online: http://eprints.soas.ac.uk/23032/

in cash, labour or in kind. The cost of the credit is likely to be raised by uncertainty about any future income.

First, it would be uncertain whether the villager could obtain the labour on which payment would depend. Second, it would be uncertain whether the villager had other debts against that labour income, restricting their ability to repay on time or at all. Third, it would be uncertain if the person doing the labour would be paid in cash or in a form that would enable them to pay off the credit. The supplier of the credit could be expected to take that uncertainty into account and charge a price for them. In all respects, a basic income of an equal amount would be more valuable than a means-tested or conditional cash transfer.

\section{A summing up}

Consider the dynamics in a typical low-income village following the introduction of a basic income. The inflow of money provides liquidity, as well as prospective income - people know they should receive more in coming months - enabling them to reduce debt or avoid going into new debt in order to purchase goods.

It also enables some to avoid buying on expensive credit and some to accumulate savings, in order to plan to buy when prices are seasonally lower, or giving the freedom to buy at regular or longer intervals (fewer costly trips to markets). And it enables some to pool the basic income with family and community members to cover sudden demands, on a reciprocal basis. All of these lower transaction costs, which raises the basic income's net value.

The basic income represents money entering the villages that cheapens borrowing and credit costs. The cost of money drops, raising the emancipatory value, by the following savings

- reduced loans and debt,

- reduced interest on outstanding loans,

- a lower tendency to buy food or other goods on credit,

- higher purchases of productive inputs such as seeds and fertilizers,

- interest-free loans or transfers from family or neighbours to meet needs arising from shocks and hazards.

We cannot know the full effects of these changes, but if, say, three-quarters of villagers customarily borrowed each year, and if we knew how much on average they borrowed and how much the average interest rate was both before the start of the pilot and after some months, we could estimate the basic income's emancipatory value.

Other factors would have to be considered too, notably the need to borrow at all, the need to borrow from moneylenders per se, the ability to repay due to enhanced earnings from higher economic activity (shown in Davala et al., 2016, ch. 8), and the scope for pooling savings and income. Such feedback effects are rarely taken into account in assessments of social policies.

In sum, the emancipatory value of a basic income exceeds its monetary value as a result of the following tendencies: 
(a) It reduces the need to borrow, through providing current and prospective liquidity.

(b) It reduces the tendency to have to borrow at vulnerable moments, when a moneylender can take even more advantage of the supplicant than usual.

(c) It reduces the cost of borrowing, by lowering the interest rate, because the moneylender has more confidence in the ability of the borrower to repay.

(d) It reduces the need to borrow from high-interest moneylenders because of the existence of others able to lend from their basic income.

(e) It increases the ability to pay back loans, and to do so on time.

(f) It reduces the "weakness-of-will" phenomenon associated with lump-sum payments and with lumpy earned income, most powerful in and after the harvest season in which wage labour is concentrated. ${ }^{9}$

(g) It reduces dependency risk, the need to borrow from landlords on condition that the borrower sells only to the lender or sells labour as and when the lender requires.

(h) It induces a "saving habit" through a shift to institutionalised saving, in a bank or cooperative, and by providing a steady flow of money, which strengthens resilience at moments of financial crisis. One way of putting this is that the basic income facilitates, encourages and reinforces financial citizenship.

(i) Partly by inducing financial inclusion, through the opening of bank or cooperative society accounts, the basic income has a multiplier effect on the supply of money in the local economy, further cheapening its "price". It gives the bank or cooperative an opportunity to lend at market rates, not at the monopolistic rates that oligopolistic moneylenders can demand. And it draws passive money from "under the bed" into the local economy.

(j) A basic income acts as an insurance, recognising that lack of insurance deters people from taking entrepreneurial risk (Banerjee and Duflo, 2007). Although in the pilots under review, the basic income may have been paid only for a limited period, it would still have been a form of insurance against total loss of income and liquidity.

\section{Concluding Reflections}

“Necessitous men are not free men." - Franklyn Roosevelt, 1941

The main claim in this article is that the basic income's emancipatory value exceeds the monetary value, and so can be expected to have a bigger impact on other issues than might be imagined from just considering its modest amount. Perhaps most crucially, a basic income deprives exploiters of rent-seeking opportunities.

The article has focused on income-poor Indian villagers, for whom money is clearly a scarce commodity. But the reasoning can also be applied to the circumstances of the growing class around the world, the precariat (Standing, 2011, 2014). They obtain money income only

\footnotetext{
${ }^{9}$ Weakness-of-will is the term used to describe the temptation to splurge for someone receiving a lump sum. This is a reason for differentiating studies of the impact of lottery wins from that of a regular basic income.
} 
This is the accepted version of an article published by De Gruyter in Basic Income Studies 10 (2), 193-223, final version available at: http://www.degruyter.com/abstract/j/bis.2015.10.issue-2/bis-2015-0021/bis-2015-0021.xml

Accepted Version downloaded from SOAS Research Online: http://eprints.soas.ac.uk/23032/

erratically, face constant economic uncertainty and are reduced to being supplicants, dependent on charity and the discretionary decisions of state bureaucrats.

As a long-term trend, the precariat's real wages will continue to decline, in a context in which people try to maintain a habituated level of living. Indebtedness has become an ingrained feature of the precariat, whether in the form of student debt, bank and credit card debt, or "payday loans" at horrifyingly high rates of interest. In such circumstances, for those in the precariat, we may confidently conclude that a basic income would have an emancipatory value that would be much greater than its monetary value.

We should also reflect on the relationship between economic security and freedom. Drawing on Aristotle, we can say that freedom exists when a person is able to self-direct rationally to those ends he or she regards as desirable (Walsh, 1997). Full freedom in this sense requires economic security, such that people feel confident to take the risks necessary to achieve those ends.

In addition, however, a basic income enhances so-called "republican freedom". Conventional liberal notions depict freedom as non-interference in a person's decision-making. The limitation of that perspective is that it leaves open situations, relationships or structures in which some people are in a dominating position in which to interfere if they wish, while structures or customs limit or determine choices (Pettit, 2014). By contrast, republican freedom means being free of domination. A basic income would enhance republican freedom by reducing the scope for domination, and by reducing the potential costs of retribution.

An example arose during the pilots. In one village, the young women were virtually imprisoned by their cultural traditions; they felt that they had to wear veils in public or risk the wrath and retribution of the elders. When registering to receive the basic income for the first time, they were required to have their photographs taken in order to be identifiable as recipients. It was arranged that they could do so in private.

On visiting the village some months later, the project team observed that they had gained sufficient confidence from having their own money income that almost all of them had dispensed with the veils and were seen to be chatting in the centre of the village. In effect, the basic income had countered a form of cultural domination and helped embolden them to make decisions for themselves, moderately strengthening their cultural rights. Lifting the veil allowed them to participate more freely in village life. They could pass "the eyeball test", the ability to look others in the face without having to give in to their will.

Another instance was a personal experience. Going to one village to participate in the initial Awareness Day, I went to a run-down part where the "untouchables" lived. The upper caste men in the village centre were furious, having previously been very friendly. The resultant tension lasted for several weeks, during which we were worried that the village would have to be dropped from the pilot. Eventually, the pilot proceeded. Some months later, on returning to the village, the children of the untouchables were in the village school (with their own 
This is the accepted version of an article published by De Gruyter in Basic Income Studies 10 (2), 193-223, final version available at: http://www.degruyter.com/abstract/j/bis.2015.10.issue-2/bis-2015-0021/bis-2015-0021.xml

Accepted Version downloaded from SOAS Research Online: http://eprints.soas.ac.uk/23032/

eating utensils, without which they would not have been allowed to enter). It was a small change with touching social implications. It was an emancipation of sorts.

\section{References:}

Banerjee, A.V., and Duflo, E. (2007), 'The Economic Lives of the Poor', Journal of Economic Perspectives, Vol.21, No.1, pp. 141-168.

Davala, S., Jhabvala, R., Kapoor Mehta, S. and Standing, G. (2015), Basic Income: A Transformative Policy for India. New Delhi and London: Bloomsbury.

Jhabvala, R., and Standing, G. (2010), "Targeting to the "poor": Clogged pipes and bureaucratic blinkers', Economic and Political Weekly, Vol.XLV, Nos.26-27, 26 June, pp.239-46.

Lipton, M. (1968), 'The theory of the optimising peasant', Journal of Development Studies, Vol.4, No.3, pp.327-51.

Knüpfer, S., Rantapuska, E.H., and Sarvimäki, M., (2013). 'Labour market experiences and portfolio choice: Evidence from the Finnish Great Depression'. London: London Business School, Working Paper.

Mani, A., Mullainathan, S., Shafir, E., and Zhao, J. (2013), 'Poverty Impedes Cognitive Function', Science, Vol. 341, pp. 976-80.

Mullainathan, S., and Shafir, E. (2013), Scarcity: Why Having Too Little Means So Much. London: Allen Lane.

Rosenzweig, M.R and Wolpin, K.I. (1993), 'Credit market constraints, consumption smoothing, and the accumulation of durable production assets in low-income countries: Investment in bullocks in India', Journal of Political Economy, Vol.101, No.2, pp.223-44, April.

SEWA Bharat (2014), A Little More, How Much It Is...Piloting Basic Income Transfers in Madhya Pradesh, India. New Delhi, UNICEF. Available at: http://unicef.in/Uploads/Publications/Resources/pub_doc84.pdf

Standing, G. (ed.) (2005), Promoting Income Security as a Right: Europe and North America. London: Anthem Press.

Standing, G. (2006), 'CIG, COAG and COG: A comment on a debate', in E.O. Wright (ed.), Re-designing Distribution: Basic Income and Stakeholder Grants as Cornerstones for an Egalitarian Capitalism. London and New York: Verso.

Standing, G. (2011), The Precariat: The New Dangerous Class. London and New York: Bloomsbury Press. 
This is the accepted version of an article published by De Gruyter in Basic Income Studies 10 (2), 193-223, final version available at: http://www.degruyter.com/abstract/j/bis.2015.10.issue-2/bis-2015-0021/bis-2015-0021.xml

Accepted Version downloaded from SOAS Research Online: http://eprints.soas.ac.uk/23032/

Standing, G. (2014), A Precariat Charter: From Denizens to Citizens. London and New York: Bloomsbury Press.

Taleb, N.N. (2012), Anti-Fragile: How to Live in a World We Don't Understand. London: Allen Lane.

Walsh, M.M. (1997), 'Aristotle's conception of freedom', Journal of the History of Philosophy, Vol.35, No.4, October 1997, pp.495-507. 